\section{Growth and Development Responses of Ornamental Gingers to Photoperiod}

\author{
Mauricio J. Sarmiento and \\ Jeff S. Kuehny
}

Additional indeX wORds. Curcuma alismatifolia, C. cordata, C. petiolata, C. thorelii, Kaempferia, Siphonichilus decora, S. kirkii, dormancy, photoperiod, rhizomes, t-roots

Summary. Rhizomes of Curcuma alismatifolia 'Chiang Mai Pink' and tissue cultured plants of C. cordata, C. petiolata 'Emperor', C. thorelii, Kaempferia sp. 'Grande', Siphonichilus decora and S. kirkii were grown in a greenhouse under 8-, 12-, 16-, and 20-hour photoperiods. All plants grown under the 8-hour photoperiod became dormant over a $\mathbf{1 5}$ week time period. After 90 days, most ginger species grown under the 16- and 20hour photoperiods were taller than those grown under 8 and 12 hours. A larger number of unfolded leaves was indicated for all ginger species grown under 16- and 20-hour photoperiods compared to those grown under 8 and 12-hour photoperiods except for C. thorelli. The percentage of unfolded leaves as determined by quartile indicated similar results. The number of underground rhizomes of C. alismatifolia, C. cordata, and C. petiolata increased when plants were grown at 16 and 20-hour photoperiods. The number of tuberous-roots (t-roots) increased as photoperiod decreased below 16 hours for C. alismatifolia, C. cordata, C. petiolata, Kaempferia sp. and S. kirkii. Siphonichilus decora produced no t-roots while $C$. thorelii produced the most t-roots at $\mathbf{1 6}$ hours. Vegetative growth of gingers grown in this study, except for $C$. thorelii, was maintained and increased at photoperiods of 16 and 20 hours.

137 Julian C. Miller Hall, Department of Horticulture, Louisiana State University Agricultural Center, Baton Rouge, LA 70803-2120.

Use of trade names dose not imply endorsement of the products named or criticism of similar ones not named. Louisiana State University manuscript number 02-28-0042. We would like to thank The Fred C. Gloeckner Foundation and the American Floral En dowment for supporting this research. We would also like to acknowledge Scotts Co. and Set Con Thailand for providing material for this research.
Photoperiods of 8 and 12 hours induced dormancy and t-root production of most of these gingers.

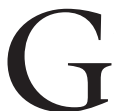
ingers are a member of the Zingiberaceae family with attractive flowers that make them useful as potted plants. These tropical and subtropical perennials are native to areas with small changes in daylength and temperature throughout the year (Zhang et al., 1995). Popularity of gingers as ornamental plants has continued to increase, and they are now commonly grown in containers under protected conditions in temperate and subtropical regions that present significant variation in daylength throughout the year (Lekawatana and Pituck, 1998). To control growth and flowering of ginger, it is necessary to understand the effects of photoperiod on vegetative and reproductive growth.

In general, gingers become dormant in winter in response to short days ( $\leq 12 \mathrm{~h}$ ) and low temperatures. Curcuma alismatifolia, a ginger native to Thailand, flowers during the summer and the fall in Israel, and in winter growth is reduced (Hagiladi et al., 1997a). Studies have demonstrated that short days and low temperatures (not specified) promote shoot dormancy in C. alismatifolia (Zhang et al., 1995). Other species of Curcuma tend to respond to short days (not specified) by becoming dormant (Lekawatana and Pituck, 1998). Globba winitii, another member of the Zingiberaceae, senesces in winter as a short-day response (Kuack, 1998).

Curcuma alismatifolia, along with most Curcuma species, has two underground storage organs: a rhizome and a spherical tuberous root designated as a t-root, attached to the rhizome by a connecting root (Hagiladi et al., 1997b). Tuberous roots ( $\mathrm{t}$-roots) have been indicated to have an important role in growth and flowering of the plant. Two or more t-roots per propagule reduced time to bloom by $18 \mathrm{~d}$, and produced more inflorescences per plant with longer scapes (Hagiladi et al., 1997b).

The objectives of this experiment were to determine the effect of photoperiod on plant growth and development of Curcuma alismatifolia 'Siam Tulip White', C. cordata, C. petiolata 'Emperor', C. thorelii'Chiang
Mai Dwarf', Kaempferia 'Grande', Siphonichilus decora, and S. kirkii.

\section{Materials and methods}

Tissue culture plants of $C$. petiolata 'Emperor', C. thorelii and Kaempferia 'Grande' S. decora, $S$. kirkii were planted one per $15.2-\mathrm{cm}$ diameter (6-inch) container in the greenhouse on 16 Aug. 1999. Tissue culture plants of $C$. cordata were planted two per 15.2 -cm-diameter container on 9 Sept. 1999. Rhizomes of Curcuma alismatifolia 'Siam Tulip White' (lacking t-roots) were planted one per 12.7-cm (5-inch) container on 27 Aug. 1999. The substrate consisted of $50 \%$ peatmoss, $30 \%$ pine bark, and $20 \%$ perlite $(\mathrm{v} / \mathrm{v})$, amended with 5.1 $\mathrm{kg} \cdot \mathrm{m}^{-3}\left(0.32 \mathrm{lb} /\right.$ yard $\left.^{3}\right)$ dolomite limestone and triple superphosphate 2.7 $\mathrm{kg} \cdot \mathrm{m}^{-3}\left(0.17 \mathrm{lb} / \mathrm{yard}^{3}\right)$ 0N-18P-0K. Plants were watered immediately after planting and drenched with a tank mix of metalaxyl (Subdue 2E; Novartis, Greensboro, N.C.) and PCNB quintozene (Terraclor 75\% WP; Uniroyal Chemical, Middlebury, Conn.). Containers were spaced $20.3 \times 20.3-\mathrm{cm}$ ( 8 inches) centers and fertigated with 24N-3.5P-13.3K (Peters 24-8-16 Tropical Foliage; Scotts Co., Marysville, Ohio) at $150 \mathrm{mg} \cdot \mathrm{L}^{-1}(\mathrm{ppm}) \mathrm{N}$.

Photoperiod treatments were initiated $17 \mathrm{~d}$ after transplanting for S. decora, S. kirkii, C. thorelii, C. petiolata and Kaempferia 'Grande', 18 d after transplanting for C. cordata and $6 \mathrm{~d}$ after planting for C. alismatifolia. There were 12 experimental units (plants) per treatment for $S$. decora, 16 per treatment of C. cordata and 3 per treatment for S. kirkii, C. thorelii, C. petiolata and Kaempferia 'Grande'. Plants in each photoperiod treatment were arranged in a complete randomized design. Plants received $8 \mathrm{~h}$ of natural light from 0900 to $1700 \mathrm{HR}$; $0,4,8$, and 12 h of supplemental light were provided for the 8-, 12-, 16-, and 20-h photoperiod, respectively. Light source was 100-W incandescent light bulbs at an irradiance of $11 \mu \mathrm{mol} \cdot \mathrm{m}^{-2} \cdot \mathrm{s}^{-1}$ $(50.0 \mathrm{fc})$ at plant height. Temperature set points in the greenhouse from planting date to 18 Oct. 1999 were $29^{\circ} \mathrm{C}$ day $/ 24^{\circ} \mathrm{C}$ night $\left(84.2^{\circ} \mathrm{F}\right.$ day $/ 75.2$ ${ }^{\circ} \mathrm{F}$ night). From 19 Oct. to the end of the experiment, temperature set points were $27{ }^{\circ} \mathrm{C}$ day $/ 21^{\circ} \mathrm{C}$ night $\left(80.6^{\circ} \mathrm{F}\right.$ day $/ 69.8^{\circ} \mathrm{F}$ night).

Each week, the number of newly unfolded leaves was counted as a 
Table 1. Effect of photoperiod on plant height for Curcuma alismatifolia 'Siam Tulip White', C. cordata, C. petiolata, C. thorelii, Kaempferia 'Grande', Siphonichilus decora, and S. kivkii after 61 and $90 \mathrm{~d}$ of photoperiod treatment.

\begin{tabular}{|c|c|c|c|c|c|}
\hline \multirow[b]{3}{*}{ Plant species } & \multirow[b]{3}{*}{ Day } & \multicolumn{4}{|c|}{$\mathrm{Ht}\left(\mathrm{cm}^{\mathrm{x}}\right)$} \\
\hline & & \multicolumn{4}{|c|}{ Photoperiod (h) } \\
\hline & & 8 & 12 & 16 & 20 \\
\hline Curcuma alismatifolia & 90 & $20.7 \mathrm{a}$ & $30.0 \mathrm{~b}$ & $38.8 \mathrm{c}$ & $35.6 \mathrm{bc}$ \\
\hline \multirow{2}{*}{ Curcuma cordata } & 61 & $42.5 \mathrm{a}$ & $44.0 \mathrm{a}$ & $45.3 \mathrm{a}$ & $46.8 \mathrm{a}$ \\
\hline & 90 & $\mathrm{D}^{\mathrm{y}}$ & $42.7 \mathrm{a}$ & $50.2 \mathrm{~b}$ & $49.0 \mathrm{~b}$ \\
\hline \multirow[t]{2}{*}{ Curcuma thorelii } & 61 & $31.3 \mathrm{a}$ & $33.0 \mathrm{ab}$ & $35.3 \mathrm{ab}$ & $37.3 \mathrm{~b}$ \\
\hline & 90 & $\mathrm{D}$ & $32.0 \mathrm{a}$ & $37.3 \mathrm{~b}$ & $38.0 \mathrm{~b}$ \\
\hline \multirow[t]{2}{*}{ Kaempferia 'Grande' } & 61 & $25.3 \mathrm{a}$ & $30.3 \mathrm{ab}$ & $38.0 \mathrm{~b}$ & $39.3 \mathrm{~b}$ \\
\hline & 90 & $\mathrm{D}$ & $31.6 \mathrm{a}$ & $46.6 \mathrm{a}$ & $46.6 \mathrm{a}$ \\
\hline Siphonichilus decora & 61 & $27.4 \mathrm{a}$ & $29.8 \mathrm{a}$ & $37.0 \mathrm{~b}$ & $41.8 \mathrm{c}$ \\
\hline
\end{tabular}

${ }^{2}$ Mean separation of photoperiods by Tukey's studentized range test, $P=0.05$. Means within rows with different letters are significantly different.

${ }^{y} \mathrm{D}=$ dormant. Plants were dormant before measurement.

${ }^{\mathrm{x}} 1.0 \mathrm{~cm}=0.39$ inches.

measurement of plant growth. On 2 Nov. and 1 Dec. 1999, plant height was measured vertically from the top of the pot to the tip of the longest leaf. The photoperiod treatments ended on 1 Feb. 2000 or after $\approx 17$ to 20 weeks of treatment. Plants that did not go dormant during the course of the experiment were forced into dormancy by terminating irrigation. After all plants were dormant, weight of underground organs (rhizomes and t-roots together) was measured and number of rhizomes and t-roots per plant was counted. Data was analyzed using PROC GLM (SAS Institute, Inc. Cary, N.C.). Comparisons between means was conducted by Tukey's studentized range test. Quartiles of new leaves were generated using PROC UNIVARIATE. Distribution in new leaves on quartiles was analyzed by chi-square and Fisher's exact test. The quartiles resulted from the division of the relative frequency of the data (number of unfolded leaves) into four intervals with each containing $25 \%$ of the measurements.

\section{Results and discussion}

All plants became dormant when grown under the 8-h photoperiod, except $S$. decora. The number of weeks required for plants to go dormant under the 8-h photoperiod was 12 weeks for C. alismatifolia, 9 weeks for C. cordata, 15 weeks for C. petiolata 'Emperor', 11.6 weeks for C. thorelii, 12 weeks for Kaempferia 'Grande', and 15.6 weeks for S. kirkii. Some plants of each species grown under the 12 -h photoperiod became dormant before the end of the 17 weeks of treatment. None of the plants however, became dormant under the 18 and 20 -h photoperiod.

Photoperiod affected height of all ginger species evaluated. Plants grown under 20- and 16-h photoperiods were taller than those grown under 12 - or 8-h photoperiods. After $61 \mathrm{~d}$, plant height of C.alismatifolia, C. petiolata,

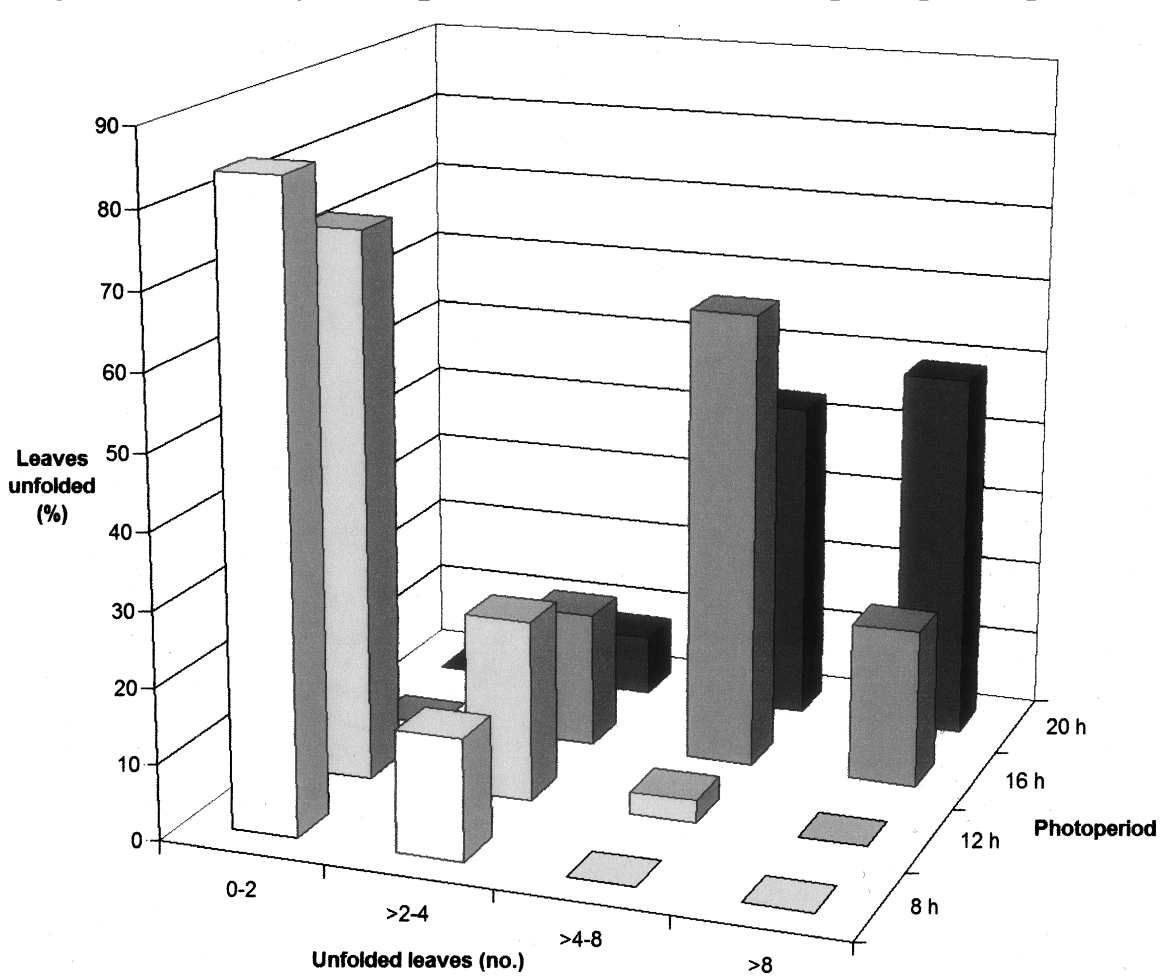

Fig. 1. Effect of photoperiod on percent of leaves unfolded as grouped by quartile of new leaves for Curcuma alismatifolia 'Siam Tulip White' after 20 weeks of photoperiod treatment.
C. thorelli and $S$. decora grown at $20 \mathrm{~h}$ was taller than those plants grown at 8 $\mathrm{h}$ (Table 1). At $90 \mathrm{~d}$ all ginger grown at $20 \mathrm{~h}$ were taller than those grown at 8 h, while Kaempferia 'Grande', $C$. cordata and $C$. thorelli had gone dormant and produced no more leaves. Similar results were found for orchid pansy (Achimenesspp.) a rhizomatous plant native from Mexico to Brazil, where a 16-h photoperiod produced 


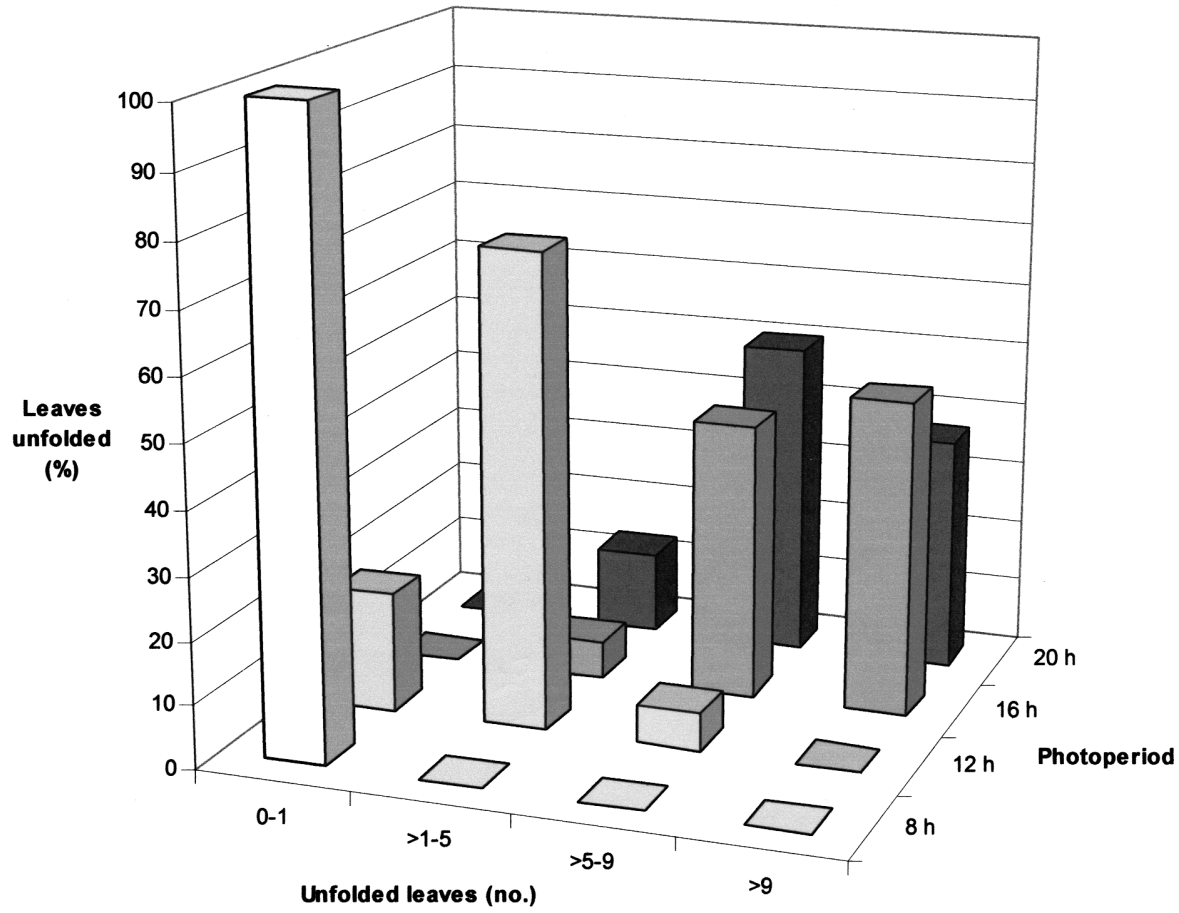

Fig. 2. Effect of photoperiod on percent of leaves unfolded as grouped by quartile of new leaves for Curcuma cordata after 17 weeks of photoperiod treatment.

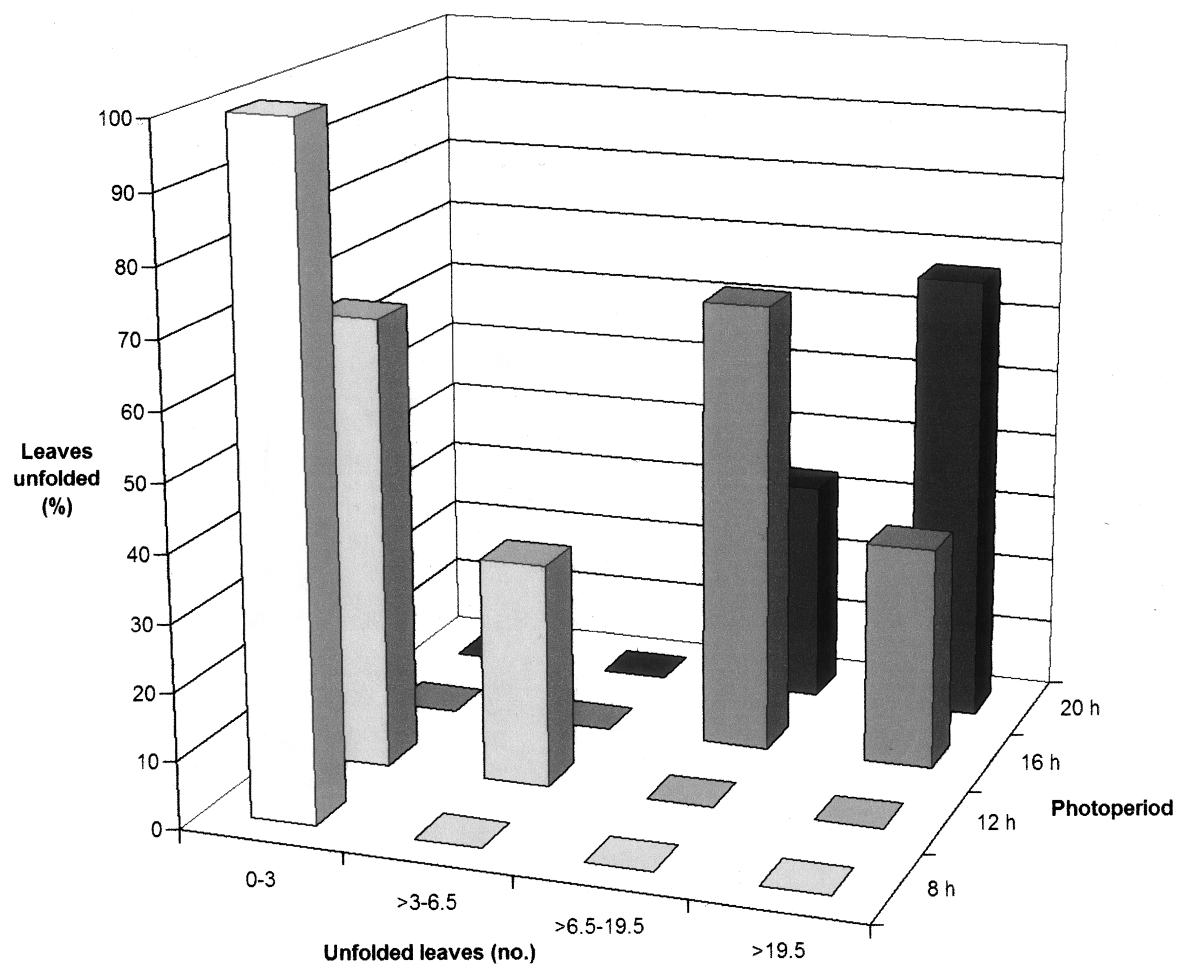

Fig. 3. Effect of photoperiod on percent of leaves unfolded as grouped by quartile of new leaves for Curcuma petiolata after 20 weeks of photoperiod treatment. significantly taller plants than an 8-h photoperiod (Vlahos, 1990).

Photoperiod affected the number of unfolded leaves of all plants, except for C. thorelii (Figs. 1-7); 16- and 20-h photoperiod increased the number of leaves unfolded compared to 12 and 8 h. For example, C. alismatifolia grown at 8 - and 12 -h photoperiods unfolded 0 to 2 leaves ( $84 \%$ and $72 \%$ respectively) during the 17-week study (Fig. 1). Of the plants grown at a $16-\mathrm{h}$ photoperiod, $60 \%$ unfolded $>4$ to 8 leaves; $43 \%$ of those grown at $20 \mathrm{~h}$ unfolded $>4$ to 8 leaves, and $48 \%$ unfolded more than 8 leaves. The percentage of unfolded leaves of Kaempferia 'Grande' in the $>3$ to 4.5 quartile was $33 \%$ for the 12-h photoperiod (Fig. 5). The 16-h photoperiod had the largest percentage in the $>10.5$ quartile $(67 \%)$. At $20 \mathrm{~h}$ the largest percentage unfolded was in the $>4.5$ to 10.5 quartile. Siphonichilus decora plants grown at $8 \mathrm{~h}(75 \%)$ and all plants grown at $12 \mathrm{~h}$ unfolded $0-2$ leaves during the 21 -week study (Figure 6). Two thirds of the plants grown under 16-h photoperiod unfolded $>5$ to 9 leaves and one third unfolded more than 9 leaves. Most plants grown at 20 h $(58 \%)$ unfolded more than 9 leaves, and $41 \%$ unfolded $>5$ to 9 leaves. Similar results were found for tuberous begonias (Begonia $\times$ tuberbybrida), another geophytic plant, where a 16-h photoperiod $(9 \mathrm{~h}$ natural light $+7 \mathrm{~h}$ supplemental) or interrupted nights (9 $\mathrm{h}$ natural light $+3 \mathrm{~h}$ supplemental light from 2300 to $0200 \mathrm{HR}$ ) increased the number of leaves and top fresh weight (Fonteno and Larson, 1982).

Effect of photoperiod on fresh weight of underground storage organs, number of rhizomes and number of $\mathrm{t}$ roots depended on the ginger species. More t-roots per plant were produced when grown under 8- or 12 -h than 20or 16-h photoperiods with as many as 1.5 more for C. alismatifolia 'Siam Tulip White', 5.9 more for C. cordata, 5.7 more for C. petiolata, 8.3 more for Kaempferia 'Grande' and one more for S. kirkii (Table 2). These results are similar to those found for dahlia (Dablia variabilis), where tuberization in the roots was promoted by short days ( 8 -h photoperiod) (Moser and Hess, 1968). Also, in tuberous begonias, tuber formation was enhanced on plants grown at short days (9 h) (Fonteno and Larson, 1982). The exception was C. thorelii, where more t-roots were produced on the plants growing at a $16-\mathrm{h}$ photope- 
riod than at $8 \mathrm{~h}$. Siphonichilus decora did not produce t-roots under any of the four photoperiods.

Curcuma alismatifolia 'Siam Tulip White' (1.3 more rhizomes), C. cordata (1.1 more rhizomes) and C. petiolata (2 more rhizomes) produced more rhizomes under the long day photoperiods (20 and $16 \mathrm{~h}$ ) than under 12 and $8 \mathrm{~h}$ (Tables 4-7). The greater numbers of t-roots and rhizomes of those plants grown under 20- and 16-h photoperiods were also reflected in increased underground organ weight with differences between 8 and $20 \mathrm{~h}$ of $8.7 \mathrm{~g}(0.31 \mathrm{oz})$ for C. alismatifolia, $28.8 \mathrm{~g}(1.02 \mathrm{oz})$ for $C$. thorelii, 41.3 $\mathrm{g}(1.46 \mathrm{oz})$ for $S$. decora and $36.4 \mathrm{~g}$ (1.28 oz) for S. kirkii. Curcuma cordata grown under 12 and $16 \mathrm{~h}$ produced heavier underground organs than at 8 h. Photoperiod did not have an effect on the weight of underground organs of Kaempferia 'Grande'.

A number of tropical plants (not specified) have been shown to be sensitive to day length (Rees, 1987). Photoperiodically responsive plants near the equator are more sensitive to small changes in daylength because of the very small seasonal day-to-day differences in daylength that occur in low latitudes. Variations in physiological response to photoperiod was observed for the different species of Zingiberaceae evaluated in this study. This was true for dormancy, weight of underground organs, number of t-roots and number of rhizomes. Such variation may be attributed to the different origin of the gingers studied. Siphonichilusoriginated in southern and eastern Africa (Huxley et al., 1992). Curcuma and Kaempferia originated in tropical Asia, where a great diversity in temperature (caused by latitude and altitude) and photoperiod (caused by latitude) occurs. In Thailand, where 30 of the 65 species of Curcuma are found, latitude varies from $5^{\circ}$ to $21^{\circ} \mathrm{N}$ and longitudes $97^{\circ}$ to $106^{\circ} \mathrm{E}$, with average temperatures from 24 to $33{ }^{\circ} \mathrm{C}\left(74.7\right.$ to $\left.90.5{ }^{\circ} \mathrm{F}\right)$ (Lekawatana and Pituck, 1998). Thus, although growth and development stages have been established by Hagiladi et al. (1997b) for C. alismatifolia, they cannot be applied to all gingers in the Zingiberaceae family.

The effect of incandescent lights used to manipulate photoperiod in this experiment may have had a confounding effect on shoot height. A 4-h light interruption using 100 -W incandescent

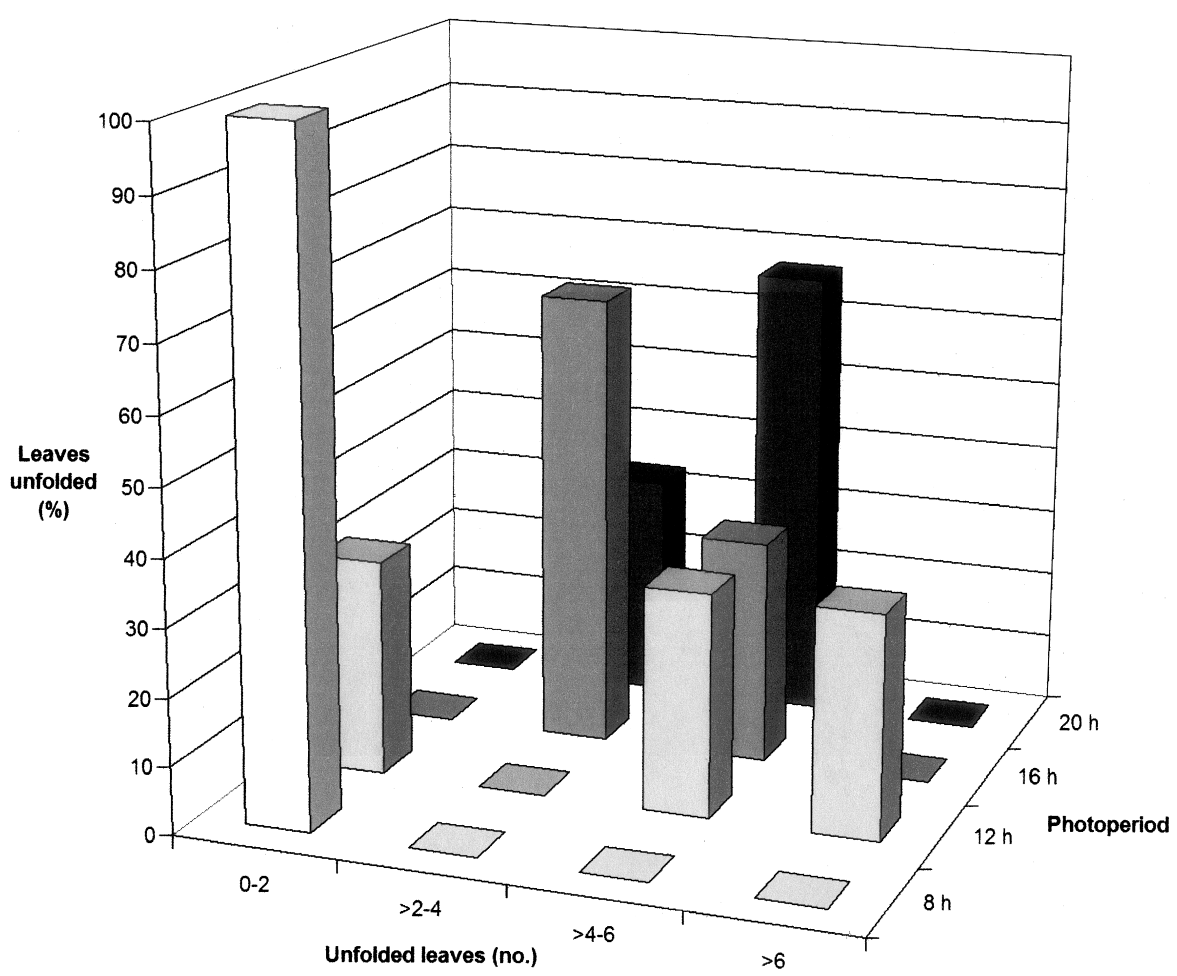

Fig. 4. Effect of photoperiod on percent of leaves unfolded as grouped by quartile of new leaves for Curcuma thorelli after 20 weeks of photoperiod treatment.

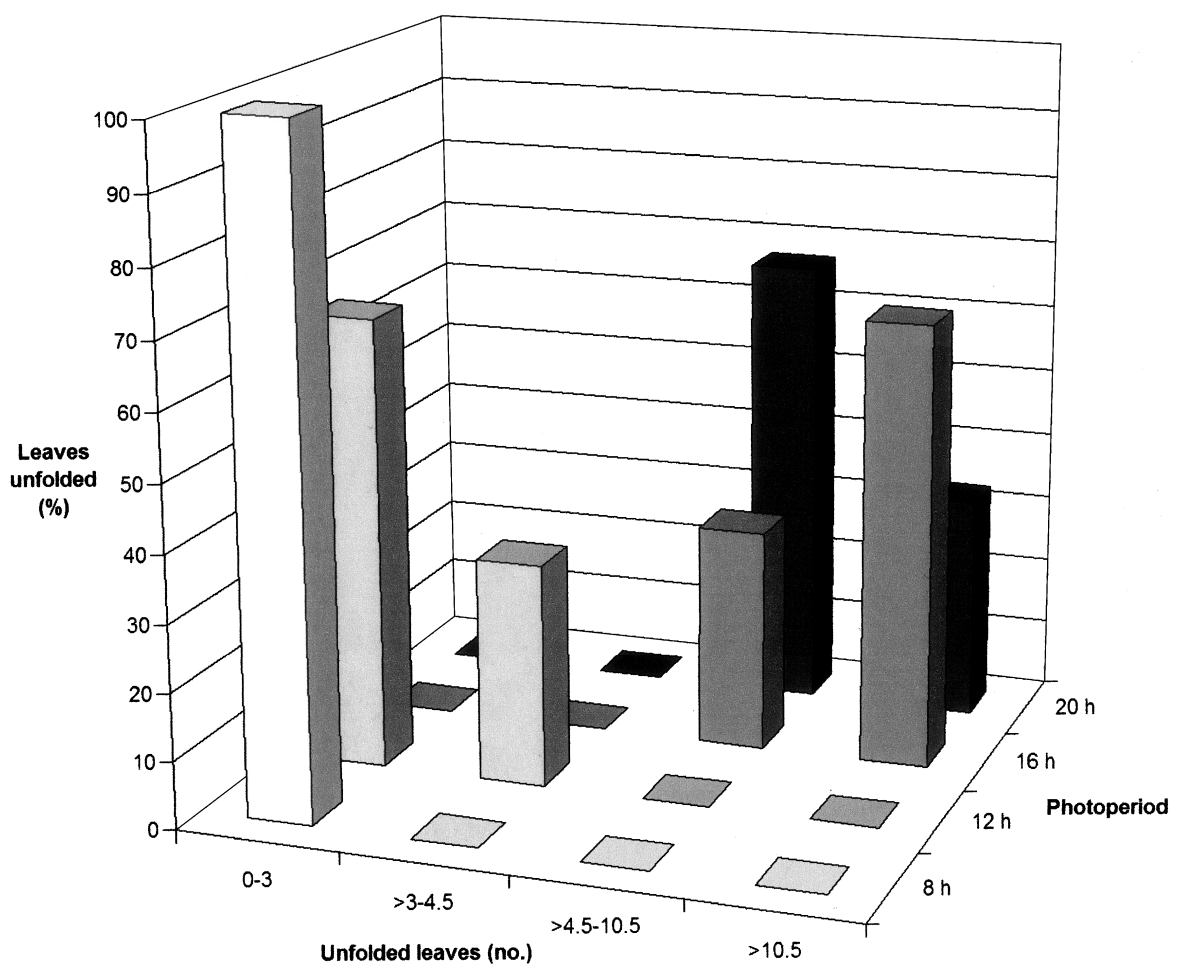

Fig. 5. Effect of photoperiod on percent of leaves unfolded as grouped by quartile of new leaves for Kaempferia sp. after 20 weeks of photoperiod treatment. 


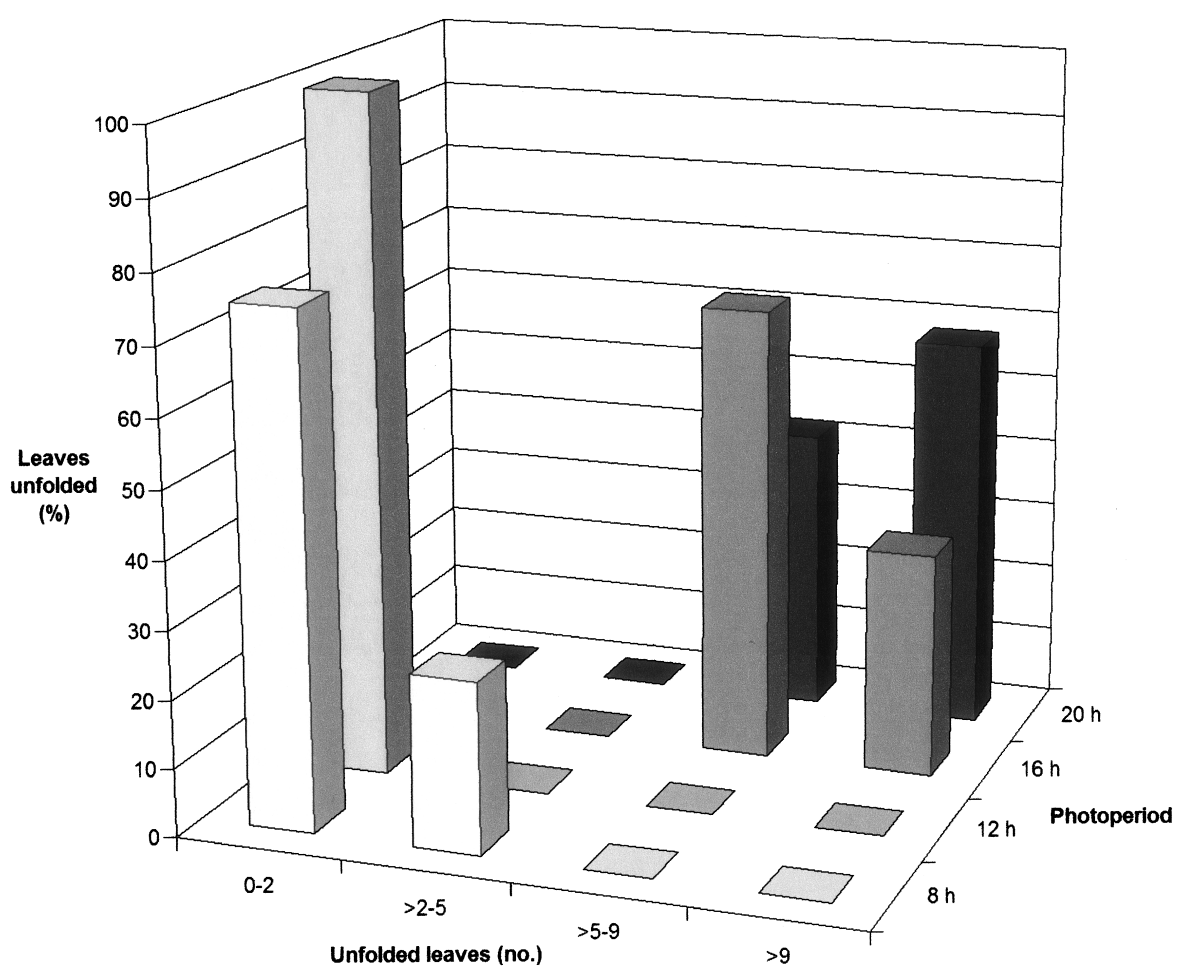

Fig. 6. Effect of photoperiod on percent of leaves unfolded as grouped by quartile of new leaves for Siphonichilus decora after 20 weeks of photoperiod treatment.

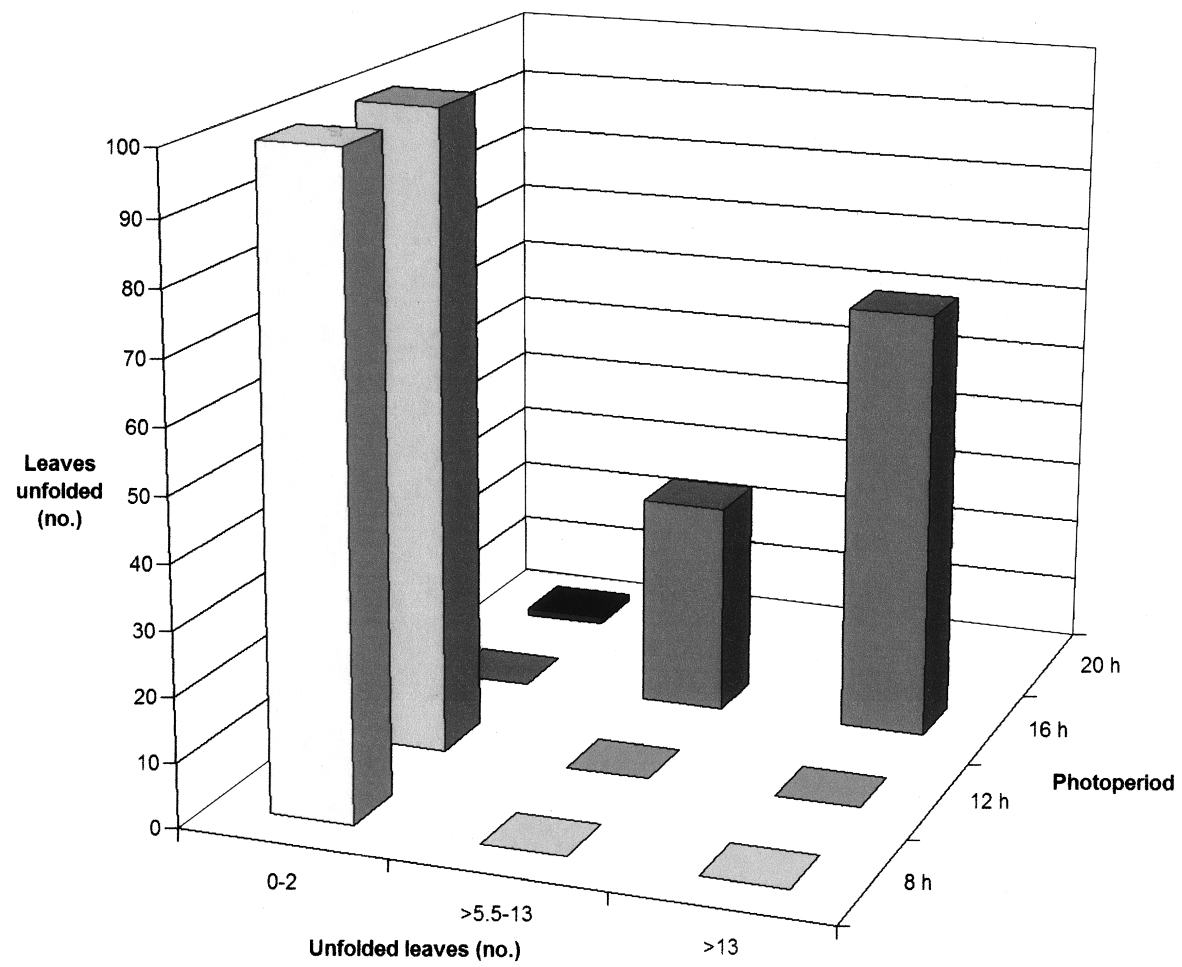

Fig. 7. Effect of photoperiod on percent of leaves unfolded as grouped by quartile of new leaves for Siphonichilus kirkii after 20 weeks of photoperiod treatment. lamps (0.39 red to far-red ratio) from 2200 to 0200 HR significantly increased plant height, node number and days to flowering of chrysanthemum (Chrysanthemum $\times$ morifolium) 'Improved Indianapolis White' and 'Golden Yellow Princess Anne' (Cathey, 1974). The increase in leaf unfolding at 16- and 20-h photoperiods and ensuing dormancy of those plants grown at an 8-h photoperiod however, indicates that despite the differences in the amount of red to far-red light these gingers received, the photoperiods were significant factors in affecting continued or increased shoot growth, or dormancy. The effect of photoperiod on flowering was not evaluated because those plants that continued to produce vegetative growth under the longer photoperiods, failed to bloom during the 17-week treatment period. Results from a photoperiod experiment conducted by Hagiladi et al. (1997a) indicated that C.alismatifolia plants began to flower after 12 weeks of growth under day lengths of 10 or $20 \mathrm{~h}$. The number of t-roots each rhizome had before the experiment was not reported and photoperiod treatments were not initiated until after 11 weeks of growth. In another study on C. alismatifolia by Hagiladi etal. (1997b), resultsindicated that rhizomes without t-roots required up to $180 \mathrm{~d}$ ( $\approx 26$ weeks) from planting to flower. Therefore, in this study where C.alismatifolia rhizomes had not-roots when planted and the remaining ginger species were from tissue culture, a longer time period may have been required to initiate flowering under long days.

Vegetative growth of most of the ornamental ginger species used in this study was optimized when plants were grown under 16- and 20-h photoperiods. An 8-h photoperiod promoted dormancy and for most species an increased number of t-roots. These results correspond to the results of Hagiladi et al (1997a) and Zhang etal. (1995) both of which reported that vegetative growth of $C$. alismatifolia was maintained by long days and dormancy was induced by short days. There was some variation in response to photoperiod by species of ginger in this study, for example $C$. thorelii and Kaempferia, and therefore the affect of photoperiod on vegetative shoot growth and development of underground storage organs is not the same for all ginger species. 
Table 2. Effect of photoperiod on fresh weight of underground storage organs, number of rhizomes per plant, and number of tuberous roots (t-roots) per plant for Curcuma alismatifolia 'Siam Tulip White', C. cordata, C. petiolata, C. thorelii, Kaempferia spp. 'Grande', Siphonichilus decora, and S. kirkii after 20 weeks of photoperiod treatment.

\begin{tabular}{|c|c|c|c|c|}
\hline \multirow{2}{*}{$\begin{array}{l}\text { Plant species and } \\
\text { response variable }\end{array}$} & \multicolumn{4}{|c|}{ Photoperiod (h) } \\
\hline & 8 & 12 & 16 & 20 \\
\hline \multicolumn{5}{|c|}{ Curcuma alismatifolia } \\
\hline wt $\left(g^{y}\right)$ & $3.6 \mathrm{a}^{\mathrm{z}}$ & $6.9 \mathrm{~b}$ & $13.7 \mathrm{c}$ & $12.3 \mathrm{c}$ \\
\hline rhizomes (no.) & $1.0 \mathrm{a}$ & $1.0 \mathrm{a}$ & $1.9 \mathrm{~b}$ & $2.3 \mathrm{c}$ \\
\hline t-roots (no.) & $2.1 \mathrm{~b}$ & $2.1 \mathrm{~b}$ & $1.9 \mathrm{~b}$ & $0.6 \mathrm{a}$ \\
\hline \multicolumn{5}{|l|}{ Curcuma cordata } \\
\hline wt $(\mathrm{g})$ & $13.2 \mathrm{a}$ & $29.9 \mathrm{~b}$ & $20.3 \mathrm{~b}$ & $15.9 \mathrm{ab}$ \\
\hline rhizomes (no.) & $1.0 \mathrm{a}$ & $1.0 \mathrm{a}$ & $1.9 \mathrm{~b}$ & $2.1 \mathrm{~b}$ \\
\hline t-roots (no.) & $5.9 \mathrm{~b}$ & $5.3 \mathrm{~b}$ & $0.0 \mathrm{a}$ & $0.0 \mathrm{a}$ \\
\hline \multicolumn{5}{|l|}{ Curcuma petiolata } \\
\hline wt $(\mathrm{g})$ & $25.6 \mathrm{a}$ & $35.6 \mathrm{ab}$ & $47.2 \mathrm{~b}$ & $44.2 \mathrm{ab}$ \\
\hline rhizomes (no.) & $1.0 \mathrm{a}$ & $1.0 \mathrm{a}$ & $1.6 \mathrm{ab}$ & $3.0 \mathrm{~b}$ \\
\hline t-roots (no.) & $6.3 \mathrm{~b}$ & $6.3 \mathrm{~b}$ & $0.3 \mathrm{a}$ & $0.6 \mathrm{a}$ \\
\hline \multicolumn{5}{|l|}{ Curcuma thoreliiwt } \\
\hline wt $(\mathrm{g})$ & $13.4 \mathrm{a}$ & $19.3 \mathrm{a}$ & $36.2 \mathrm{~b}$ & $42.2 \mathrm{~b}$ \\
\hline rhizomes (no.) & $1.0 \mathrm{a}$ & $1.0 \mathrm{a}$ & $1.0 \mathrm{a}$ & $1.0 \mathrm{a}$ \\
\hline t-roots (no.) & $6.0 \mathrm{a}$ & $8.3 \mathrm{ab}$ & $11.6 \mathrm{~b}$ & $10.6 \mathrm{ab}$ \\
\hline \multicolumn{5}{|l|}{ Kaempferia 'Grande' } \\
\hline wt $(\mathrm{g})$ & $18.1 \mathrm{a}$ & $25.2 \mathrm{a}$ & $22.6 \mathrm{a}$ & $20.2 \mathrm{a}$ \\
\hline rhizomes (no.) & $1.0 \mathrm{a}$ & $1.0 \mathrm{a}$ & $1.0 \mathrm{a}$ & $1.3 \mathrm{a}$ \\
\hline t-roots (no.) & $8.3 \mathrm{c}$ & $4.6 \mathrm{~b}$ & $0.0 \mathrm{a}$ & $0.0 \mathrm{a}$ \\
\hline \multicolumn{5}{|l|}{ Siphonichilus decora } \\
\hline wt $(\mathrm{g})$ & $15.7 \mathrm{a}$ & $17.6 \mathrm{a}$ & $45.1 \mathrm{~b}$ & $57.0 \mathrm{c}$ \\
\hline rhizomes (no.) & $1.0 \mathrm{a}$ & $1.0 \mathrm{a}$ & $1.0 \mathrm{a}$ & $1.0 \mathrm{a}$ \\
\hline t-roots (no.) & $0.0 \mathrm{a}$ & $0.0 \mathrm{a}$ & $0.0 \mathrm{a}$ & $0.0 \mathrm{a}$ \\
\hline \multicolumn{5}{|l|}{ Siphonichilus kirkii } \\
\hline wt $(\mathrm{g})$ & $22.6 \mathrm{a}$ & $19.2 \mathrm{a}$ & $55.5 \mathrm{~b}$ & $55.6 \mathrm{~b}$ \\
\hline rhizomes (no.) & $1.0 \mathrm{a}$ & $1.0 \mathrm{a}$ & $1.3 \mathrm{a}$ & $1.6 \mathrm{a}$ \\
\hline t-roots (no.) & $1.0 \mathrm{~b}$ & $0.6 \mathrm{ab}$ & $1.0 \mathrm{~b}$ & $0.0 \mathrm{a}$ \\
\hline
\end{tabular}

${ }^{2}$ Mean separation of photoperiods by Tukey's studentized range test, $P=0.05$. Means within rows with different letters are significantly different.

$28.35=1.0 \mathrm{oz}$.

\section{Literature cited}

Cathey, H.M. 1974. Participation of phytochrome in regulating internode elongation of Chrysanthemum morifolium (Ramat.) Hemsl. J. Amer. Soc. Hort. Sci. 99(1):17-23.

Fonteno, W.C. and R.A. Larson. 1982. Photoperiod and temperature effects on nonstop tuberous begonia. HortScience. 17(6):899-901.

Hagiladi, A., N. Umiel, Z Gilad, and X.H. Yang. 1997b. Curcuma alismatifolia I. Plant morphology and the effect of tuberous root number on flowering date and yield of inflorescences. Acta Hort. 430:747-753.

Hagiladi, A., N. Umiel, and X.H. Yang. 1997a. Curcuma alismatifolia II. Effects of temperature and daylength on the development of flowers and propagules. Acta Hort. 430:755-761

Huxley, A., M. Griffiths, and M. Levy. 1992. The new royal horticulture society dictionary of gardening. MacMillan, New York.

\section{Efficacy of Ethephon on Vegetative Annuals}

\author{
Terri W. Starman, ${ }^{1}$ \\ Melissa C. Robinson, ${ }^{2}$ and \\ Kristen L. Eixmann ${ }^{3}$
}

Additional INDEX WORDS. Florel, (2chloroethyl) phosphonic acid, height reduction, internode elongation

Summary. Plant response to ethephon treatment was tested on 27 cultivars of vegetative annuals that have spreading and trailing growth habits. A control treatment was compared to $\mathbf{5 0 0}$ and $1000 \mathrm{mg} \cdot \mathrm{L}^{-1}(\mathrm{ppm})$ foliar spray treatments of ethephon. Plant height and/or width index were significantly reduced for $81 \%$ of the cultivars tested. Responsive cultivars were alternanthera (Alternanthera dentata), brachyscome (Brachyscome iberidifolia) 'Toucan Tango'; calibrachoa (Calibrachoa hybrids) 'Colorburst Red', 'Million Bells Cherry Pink', and 'Trailing Pink'; diascia (Diascia xhybrida) 'Sunchimes Rose' and 'Red Ace'; double impatiens (Impatiens wallevana) 'Tioga Red' and 'Tioga White'; sweetpotato vine (Ipomoea batatas) 'Sweet Caroline Bronze'; lantana (Lantana camara) 'Patriot Cherry' and 'Samantha'; nemesia (Nemesia $\times$ bybrida) 'Aromatica Dark Lavender', 'Blue Bird', and 'Blueberry Sachet'; nolana (Nolana paradoxa) 'Blue Eyes'; ivy geranium (Pelargonium bybrida) 'King of Balcon'; petunia (Petunia $\times$ bybrida) 'Cascadia Pink', 'Mini Bright Pink', and 'Supertunia Mini Purple'; bacopa (Sutera cordata) 'Bridal Showers'; and vinca vine (Vinca minor) 'Illumination'. Ethephon was not effective on monopsis (Monopsis unidentata) 'Royal Flush',

Department of Horticultural Sciences, Mail Stop 2133, Texas A\&M University, College Station, TX 77843-2133. regulation of photoperiodism. A review, $\mathrm{p}$. 187-202. In:J.G. Atherton(ed.). Manipulation of flowering. Butterworths, London.

Vlahos, J.C. 1990. Daylength influences growth and development of Achimenescultivars. HortScience. 25(12):1595-1596.

Zhang, J.X., J.P. Huang, and L.M. Lin. 1995. A new favorite in flower markets: Cultivation technique and regulation of flowering of Curcuma alismatifolia. Taiwan Flower Ind. 92(3):36-40.
This research was funded in part by the Texas Agricultural Experiment Station. The authors wish to thank Ball FloraPlant, Bodger Botanicals, D.S. Cole Growers, EuroAmerican and The Flower Fields for donation of plant materials. Mention of a trademark, proprietary product, or vendor does not constitute a guarantee or warranty of the product by the author, Texas A\&M University, or the Texas Agricultural Experiment Station, and does not imply its approval to the exclusion of other products or vendors that also may be suitable.

${ }^{1}$ Associate professor of floriculture.

${ }^{2}$ Graduate student

${ }^{3}$ Research assistant. 